\title{
Cordonnier Grade 2 Fungal Complication, Deep Candida Infection without
} Candidemia

National Cancer Institute

\section{Source}

National Cancer Institute. Cordonnier Grade 2 Fungal Complication, Deep Candida

Infection without Candidemia. NCI Thesaurus. Code C138299.

Any deep Candida infection without candidemia. 